\title{
Morphometry Study and Integrated Management of Dibawah Lake Watershed Solok Regency
}

\author{
Raden Herdian Bayu Ash Siddiq*, Fuad Hasan, Yanyan Agustian, Ajeng Mayang KS, \\ Mohd. Haizam bin Mohd. Saudi
}

Department of Civil Engineering, Widyatama University, Indonesia

Copyright $\bigcirc 2019$ by authors, all rights reserved. Authors agree that this article remains permanently open access under the terms of the Creative Commons Attribution License 4.0 International License

\begin{abstract}
Dibawah Lake is a tectonic lake located in Solok Regency, West Sumatra. It's functioned as the West Sumatra Government as a tourist area, besides that it was also used as an irrigation water source. This study aims to obtain information on the characteristics of lake morphometry and formulate the concept of integrated management of Dibawah Lake Catchment Area. From the results of bathymetry mapping produces a lake area of 10998.1 ha with a circumference of $17.2 \mathrm{~km}$, a maximum length of $6.4 \mathrm{~km}$, a maximum width of $3 \mathrm{~km}$, a maximum depth of $326.8 \mathrm{~m}$, an average depth of $164.3 \mathrm{~m}$ and volume of 1688 million $\mathrm{m}^{3}$. The lake catchment area is 2881.7 ha and it is divided into 27 sub-catchments. The existing problems in the Dibawah Lake are (1) changes in lake area land cover into agricultural fields, (2) agricultural cropping patterns in slope areas, (3) lakefront settlements, (4) water quality degradation, (5) fish cages floating net and fishing ring. From the results of the SWOT analysis, the W-T (Weaknesses - Threats) strategy was chosen as the top priority. The W-T strategy focuses on strengthening and drafting rules, monitoring the implementation of rules, enforcing violations and socialization of the community.
\end{abstract}

Keywords Lake Dibawah, Morphometry, Lake Catchment Area, SWOT

\section{Introduction}

Lake is a large natural basin surrounded by land which then holds and deviates from water from rainwater, springs, seepage and river water. In Indonesia, observations have been made on the condition of the lakes. There are 15 priority lakes that are included in the national lake rescue program or known as GERMADAN (Lake Rescue Movement) (Kementerian LH, 2011). Some lakes including Lake Maninjau, Toba, Limboto and Rawapening are in critical condition. The causes of the critical condition are high levels of sedimentation and poor water quality (Apriyani 2017). Dibawah Lake, Diatas Lake, and Talang Lake are located in Solok Regency, West Sumatra, on the back of Bukit Barisan which extends along Sumatra Island. Diatas and Dibawah Lake or often called Twin Lakes is a tectonic lake which is located at an altitude of 1531 meters above sea level and 1462 meters above sea level (Pasilehmusluoto, 1997).

\section{Literature Review}

The study of the basin characteristics is known as lake morphology. Lake morphometry is a physical picture of the lake body about its various potentials as a source of water and biological production, as well as the sensitivity of the catchment area. To study the lake morphometry, bathymetry mapping with a method of smell is needed to obtain a picture of the shape of the lake's surface. The process of delineating the lake bottom (measurement, management, and depiction) is called a bathymetric survey (Poerbondono, 2005). Lake morphometry data is very useful for anticipating any changes in the lake system and predicting the effects on the lake.

Lake catchment area of the lake is a land area which is topographically bounded by ridges that accommodate and store rainwater which is then channeled into lakes and is an ecosystem with its main elements are soil, water, and vegetation, as well as humans as its utilization. (Asdak, 2002). The importance of integrated Lake Catchment Area management is to maintain the sustainable use of forest, land and water resources. The wrong planning can lead to Lake Catchment Area degradation which results in adverse impacts. In the integrated management of Lake Catchment Area, overall planning is needed, sustainable and environmentally sound.

The location of the study is Dibawah Lake located in Solok Regency, West Sumatra Province. A geographical Dibawah Lake position is approximately $1^{\circ} 0$ '35 "Latitude 
and $100^{\circ} 43^{\prime} 51$ East Longitude. The outflow of this lake is the Lembang River which runs on Lake Singkarak. Dibawah Lake Catchment Area is a rugged field and has been utilized for a variety of purposes such as agriculture, plantation, and settlement.

This study aims to examine the condition of Dibawah Lake Morphometry and Integrated Lake Catchment Area management.

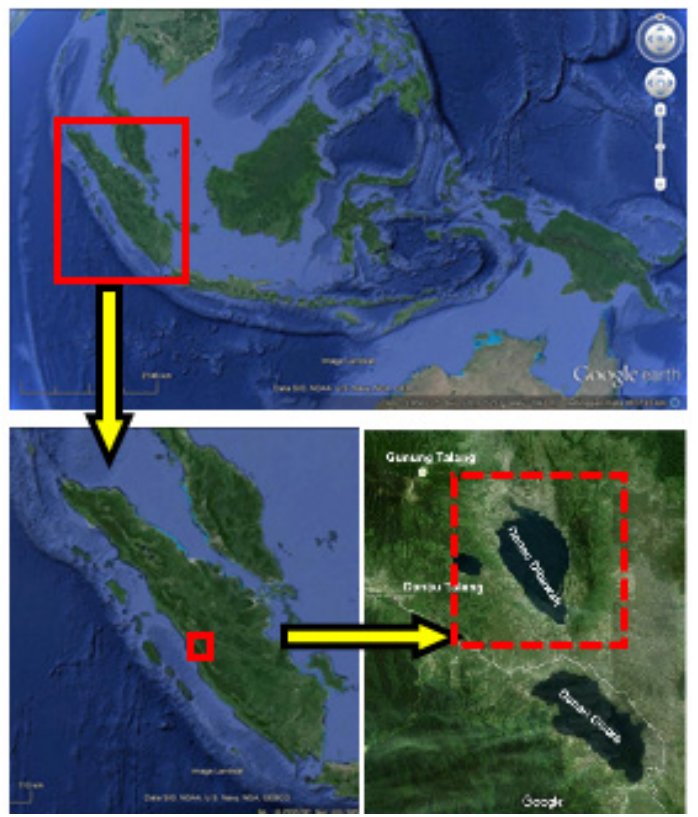

Figure 1. The location of Dibawah Lake

\section{Method}

This study is carried out through data collection, processing, and analysis in primary and secondary literature studies at universities, research institutions, relevant government institutions, to obtain references and data. In this study data and information are sourced from primary and secondary data which are then analyzed spatially to delineate Lake Catchment Area and determine lake morphometry, also using the SWOT method to approach the concept of integrated Lake Catchment Area management.

To get a bed lake elevation is done by bathymetry survey which includes mapping of lake surfaces every $50 \mathrm{~m}$ in the lakeside area and $100 \mathrm{~m}$ in the central lake area. At each track, the depth data is recorded and stored by synchronizing the position and trajectory data using Garmin Echosounder GPS

The measurement data is downloaded from GPS in the form of a table, the data line is in the form of measurement points while the column is in the form of ID data, data retrieval time, coordinates, altitude, and depth. Then the table data is changed to spatial form and processed using the Geographic Information System (GIS) Arcview 10.2 program with 3DAnalysist extension being contoured data, and DEM (Digital Elevation Model), for then lake morphometry analysis to obtain surface area, circumference, length data maximum, maximum width, maximum depth, average depth, and volume of the lake.

To determine the integrated management concept of Dibawah Lake Catchment Area, the SWOT method is used. The SWOT method is a strategic planning method used to evaluate strengths, weaknesses, opportunities, and threats. In applying this analysis the location of the study is elaborated and discussed in terms of what are the Strengths (S), Weaknesses (W), Opportunities (O) and Threats (T) in the Lakes area. From the description, then the weighting and ranking are given based on the level of importance and current needs. After that, the strategy is determined which is the biggest weight (handling priority) whether the $\mathrm{S}-\mathrm{O}$, S-T, WO or WT strategy. After determining which strategy is the priority, then each strategy is outlined based on its priorities. The final stage is to load it in the form of a Lake Management Matrix.

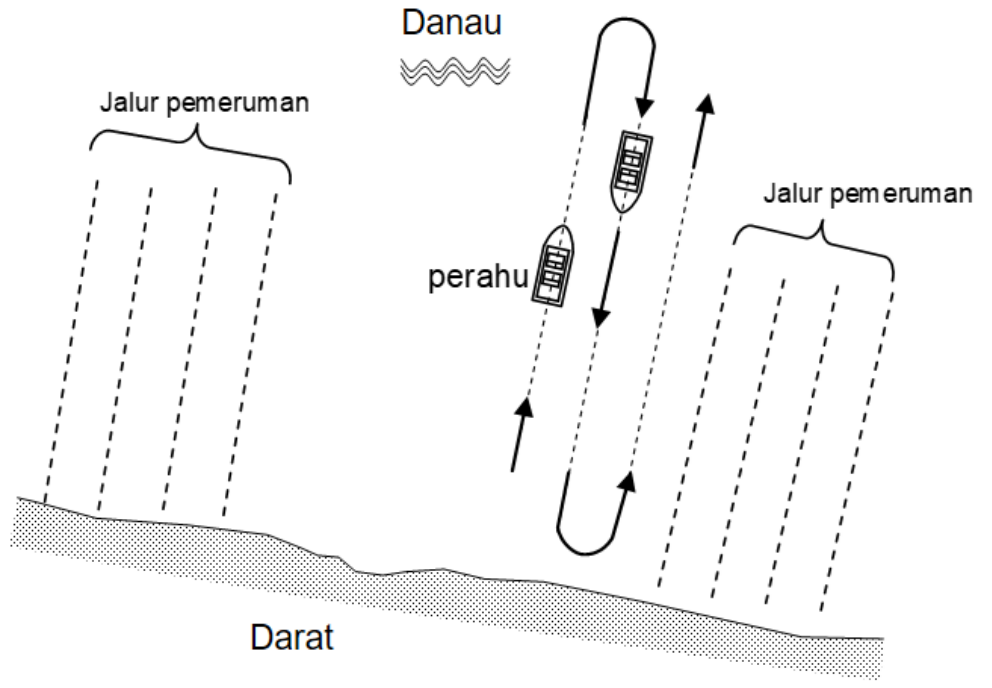




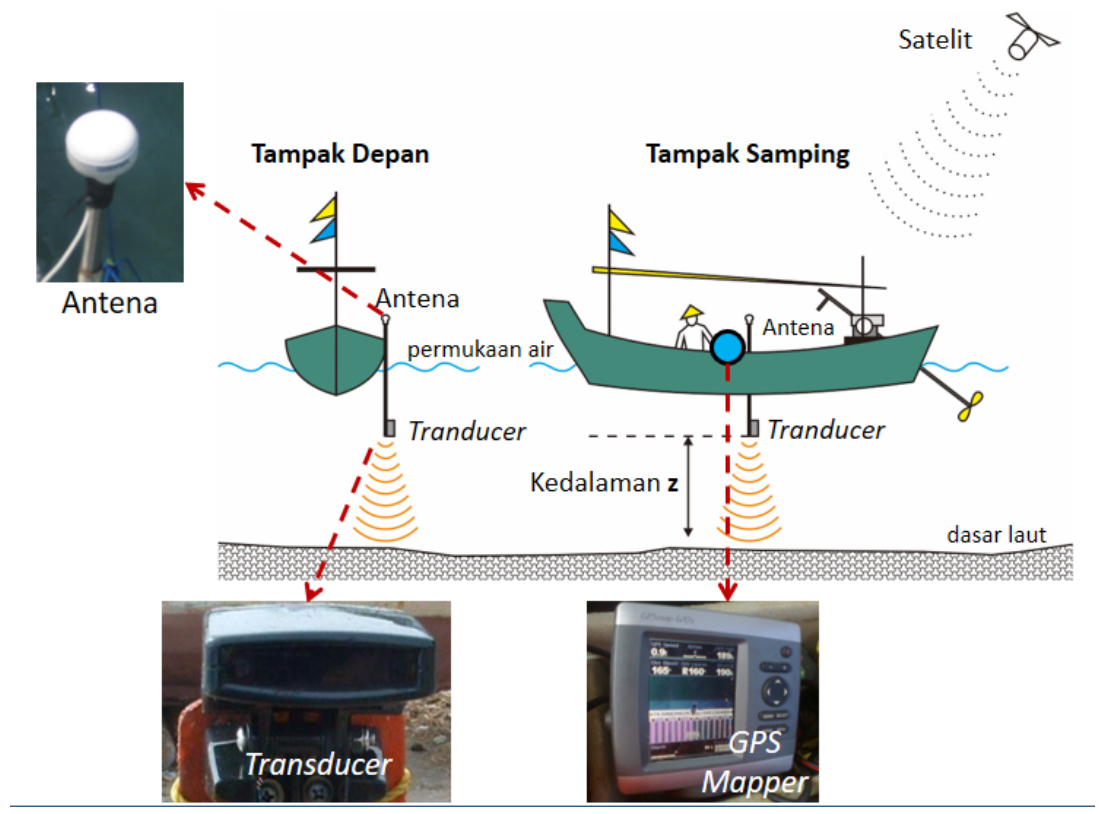

(b)

Figure 2. (a) lintasan pemeruman (b) setting alat survei

\section{Result and Analysis}

\subsection{Dibawah Lake Catchment Area}

Lake Catchment Area delineation process is using secondary data DEM SRTM (Shuttle Radar Terrain Model). This data can be downloaded for free. The DEM data is then converted into a contour to determine the highest elevations (mountain range) as the Lake Catchment Area limit. From the results of the analysis of the total area of the Dibawah Lake Catchment is 2881.7 ha divided into 27 sub-catchments.

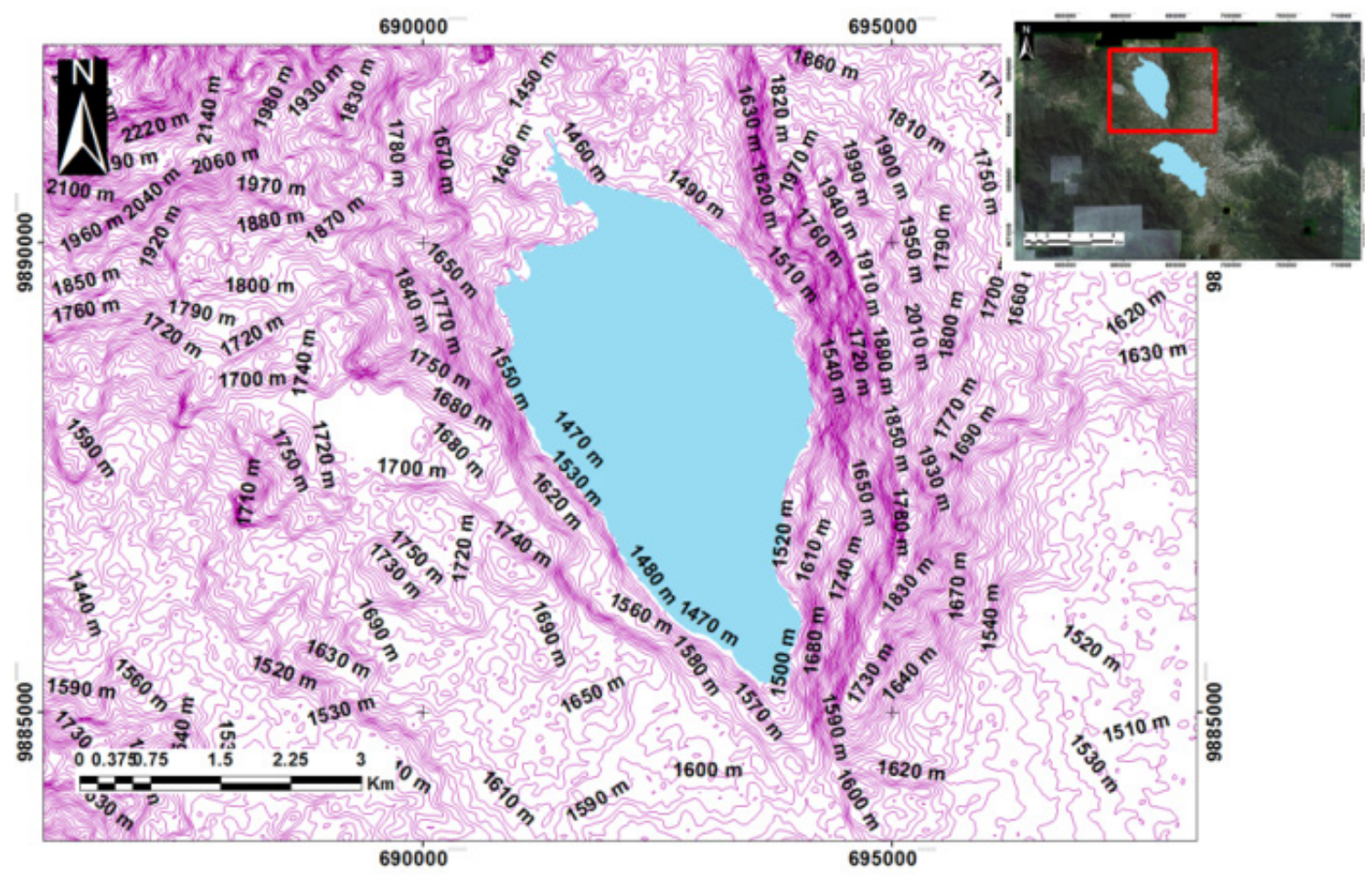

(a) 


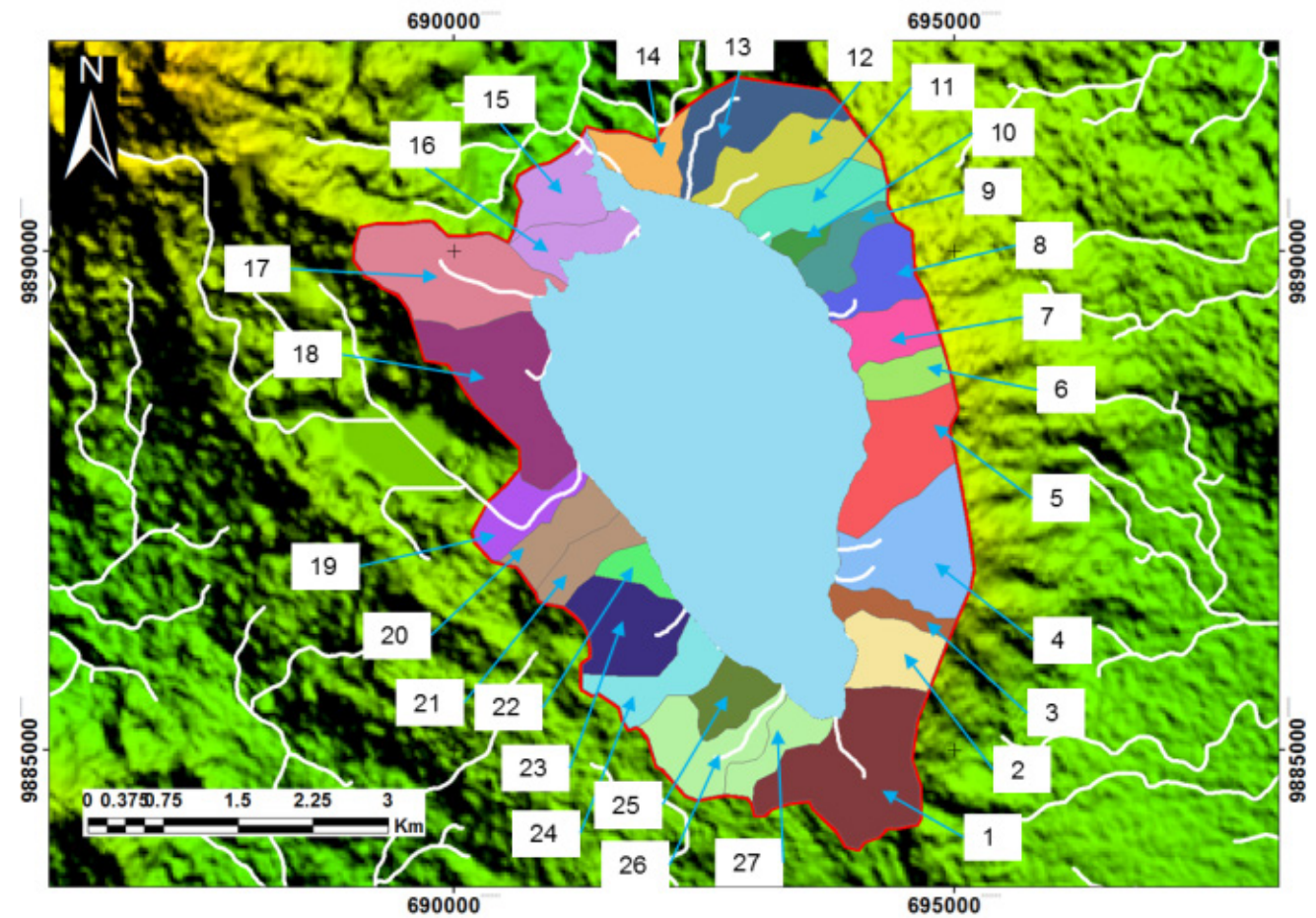

(b)

Figure 3. (a) Contour Map Dibawah Lake (b) DEM map Dibawah Lake Catchment Area

\subsection{Dibawah Lake Morphometry}

After bathymetry data was downloaded and processed into the Lake Bathymetry Map, then the morphometric parameters of the lake were calculated including surface area, circumference, maximum length, maximum width, maximum depth, average depth and volume of the lake.

Table 1. Dibawah Lake Morphometry

\begin{tabular}{|c|l|c|c|}
\hline No & \multicolumn{1}{|c|}{ Parameter } & Satuan & Hasil \\
\hline $\mathbf{1}$ & Surface Area & ha & 1099.8 \\
\hline $\mathbf{2}$ & Circumference & $\mathrm{km}$ & 17.2 \\
\hline $\mathbf{3}$ & Maximum Length & $\mathrm{km}$ & 6.4 \\
\hline $\mathbf{4}$ & Maximum Width & $\mathrm{km}$ & 3.0 \\
\hline $\mathbf{5}$ & Maximum Depth & $\mathrm{m}$ & 326.8 \\
\hline $\mathbf{6}$ & Average Depth & $\mathrm{m}$ & 164.3 \\
\hline $\mathbf{7}$ & Volume & million $\mathrm{m}^{3}$ & 1688 \\
\hline
\end{tabular}




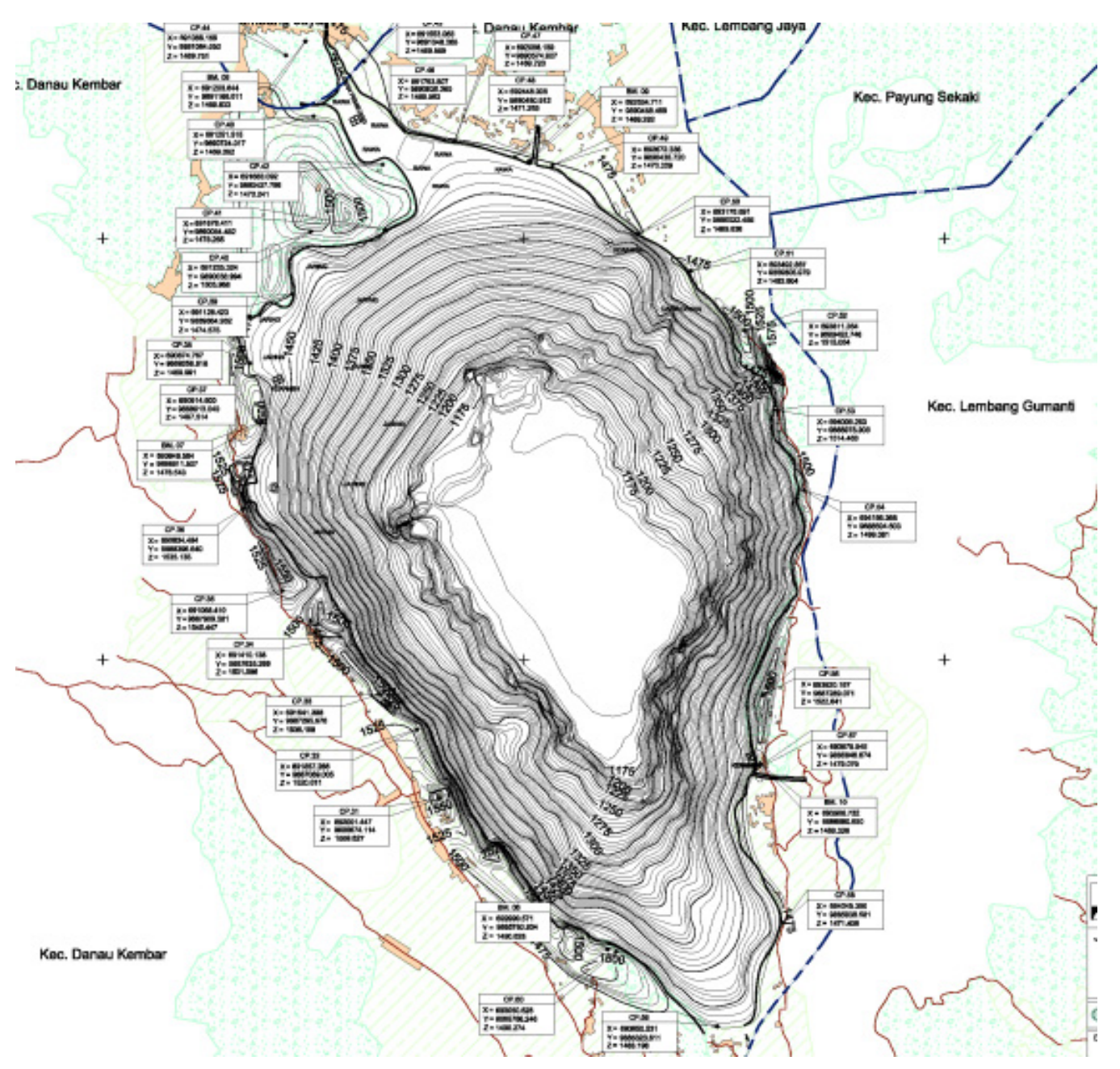

(a)

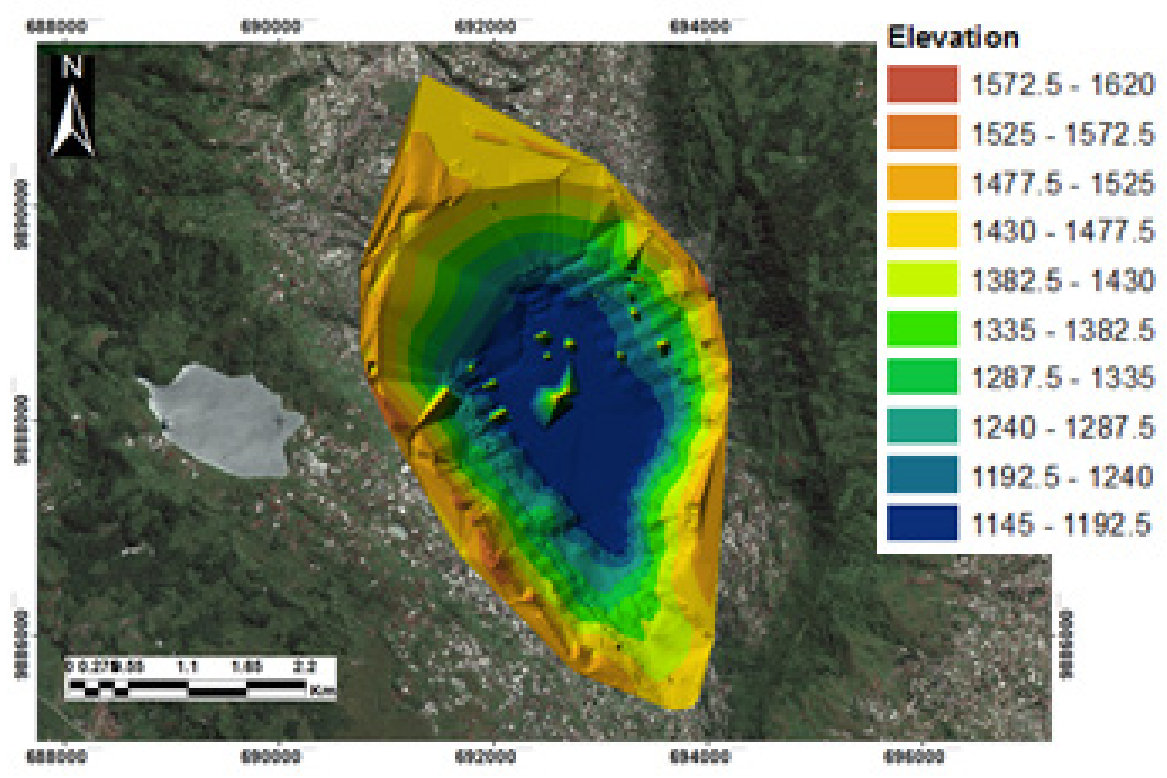

(b)

Figure 4. (a) Dibawah Lake Bathymetry Map (b) Dibawah Lake Bathymetry DEM 


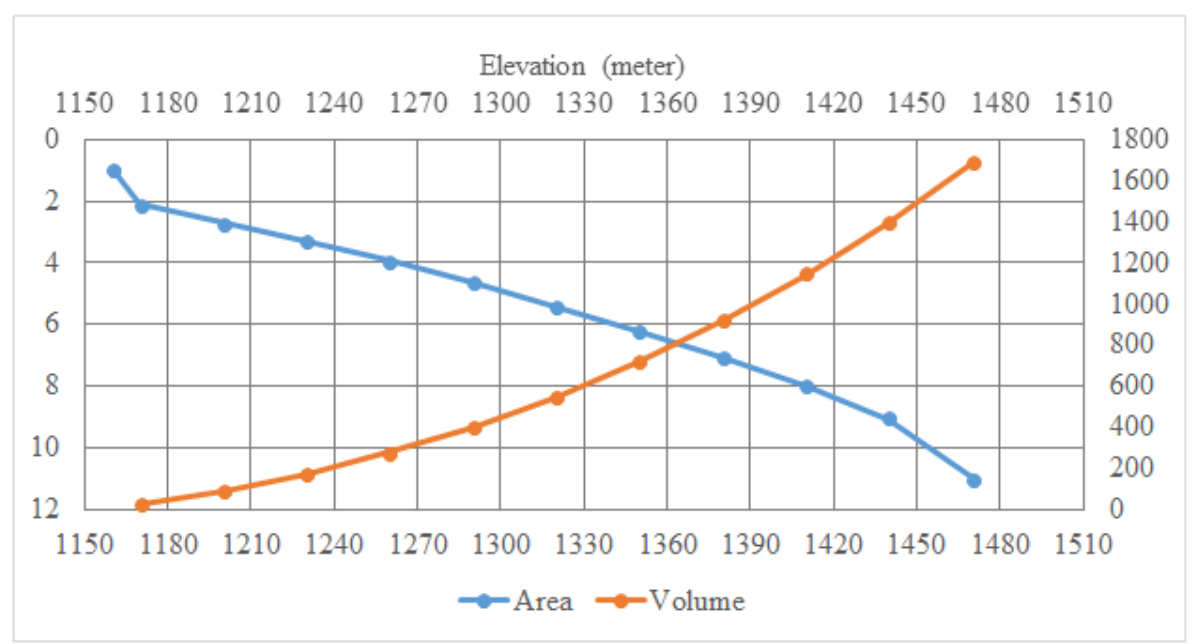

Figure 5. Comparison chart of Dibawah lake area and volume

\subsection{Integrated Lake Catchment Area Management}

By using the SWOT analysis approach with a weighting and scoring system for each factor, it is found that the W-T (Weaknesses - Threats) strategy is a priority to be implemented first with a weight of 34, then the W-O (Weaknesses-Opportunities) strategy with a weight of 31, the S-T strategy (Strengths - Threats) with a weight of 27 and an S-O strategy (Strengths-Opportunities) with a weight of 24.

Table 2. Internal and External Factor Weighting and Scoring

\begin{tabular}{|c|c|c|c|c|c|}
\hline Internal Factor & Parameter & Score & Rate & $\mathbf{S} \times \mathbf{R}$ & Total \\
\hline \multirow{4}{*}{ Strength (S) } & Water availability potential & 1 & 4 & 4 & \multirow{4}{*}{9} \\
\hline & Natural beauty potential & 1 & 3 & 3 & \\
\hline & Local fisheries potential & 0 & 1 & 0 & \\
\hline & Fertile land potential & 1 & 2 & 2 & \\
\hline \multirow{7}{*}{ Weaknesses (W) } & Don't have an inlet from a river & 0 & 1 & 0 & \multirow{7}{*}{16} \\
\hline & Decrease in water quality & 1 & 4 & 4 & \\
\hline & Lake of tourist facilities and infrastructure & 0 & 1 & 0 & \\
\hline & Lack of natural resources facilities & 0 & 1 & 0 & \\
\hline & The existence of the building on the lake border & 1 & 4 & 4 & \\
\hline & Lack of public awareness of the lake sustainability & 1 & 4 & 4 & \\
\hline & Lack of governance rules & 1 & 4 & 4 & \\
\hline External Factor & Parameter & Score & Rate & $\mathbf{S} \times \mathbf{R}$ & Total \\
\hline \multirow{4}{*}{ Opportunities (O) } & Water supply from Lake Catchment Area & 1 & 4 & 4 & \multirow{4}{*}{15} \\
\hline & Tourism site & 1 & 3 & 3 & \\
\hline & People support & 1 & 4 & 4 & \\
\hline & Agricultural and Plantation potential & 1 & 4 & 4 & \\
\hline \multirow{7}{*}{ Threats (T) } & Land use changes & 1 & 4 & 4 & \multirow{7}{*}{18} \\
\hline & Use of chemicals in agricultural activities & 1 & 4 & 4 & \\
\hline & Wrong cropping patterns of slopping land & 1 & 3 & 3 & \\
\hline & Land erosion & 1 & 3 & 3 & \\
\hline & Lake sedimentation & 0 & 1 & 0 & \\
\hline & Land use at the lake border & 1 & 4 & 4 & \\
\hline & Floating net fish cages development & 0 & 1 & 0 & \\
\hline
\end{tabular}




\begin{tabular}{|c|c|c|c|}
\hline Scoring & Ket & Rating & Ket \\
\hline $\mathbf{1}$ & Most Important & 1 & Weak \\
\hline $\mathbf{0}$ & Not Important & 2 & Average \\
\hline & & 3 & Strong \\
\hline & & 4 & Very Strong \\
\hline
\end{tabular}

The description of each strategy is as follows:

- W-T Strategy

- Increased supervision, licensing, and control over the Land Use in the Lake Area.

- Checking business licenses and land use for lawbreakers

- Implementation of a conservation agriculture system with the concept of adaptation and modification of land management at high slopes.

- Making, determining, and structuring the lake border zone

- $\quad$ Periodic checking of lake water quality

- Making zoning of water areas

- Use of vegetable pesticides and organic fertilizers

- Making, determining, and structuring fishing zones and fish cages floating net

- Socialization and counseling on the importance of the sustainability of the Lake and its area

- Creation of rules and guidelines on lake management

- $\quad$ Sediment control leading to lakes and those in the lake body.

- W-O Strategy

- Erosion control in the form of land rehabilitation

- $\quad$ Sediment dredging

- Community empowerment for alternative economic activities that do not damage the lake ecosystem.

- Provision and maintenance of various tourism infrastructure and facilities on the Lake.

- Development of environmentally tourism in the area of Dibawah Lake.

- Encouraging cooperation between various parties to improve water quality and lake ecosystems.

- Establishment of a lake authority organization.

- Supervision of people activities around Dibawah Lake.

\section{- $\quad$ S-T Strategy}

- Encouraging the arrangement of spatial and zoning regulations, especially in the Lake Catchment Area and Lake Body areas, which pay attention to aspects of Lake Rescue.

- Assistance and supervision of the use of chemicals, especially for Fertilizers and Pesticides.
- Encourage the concept of conservation from Solok Regency Government to increase the economic value in the future.

- $\quad$ S-O Strategy

- Making Zoning of Lakes and Regions to save existing potential.

- Conduct socialization and counseling to the community about the importance of preserving the Lake and its Area.

- Tourism development and promotion

- Provision of facilities and supporting infrastructure for natural resources.

- Development of agriculture and plantations in accordance with regulations and designation

\section{Conclusions}

1. The Dibawah Lake Catchment Area is 2881.7 ha divided into 27 sub-catchments.

2. The water surface area of the Dibawah Lake reaches 1099.8 ha, with a circumference of $17.2 \mathrm{~km}$, a maximum length of $6.4 \mathrm{~km}$, a maximum width of 3 $\mathrm{km}$, a maximum depth of $326.8 \mathrm{~m}$, an average depth of $164.3 \mathrm{~m}$ and a volume of 1688 million $\mathrm{m}^{3}$.

3. Problems in the Dibawah Lake are (1) changes in land cover of the lake area into agricultural fields, (2) cropping patterns in slope areas, (3) settlements on the lake border area, (4) decreasing water quality, (5) fish cages floating net and fishing ring.

4. To solving all the problems in the Dibawah Lake, an integrated Lake Catchment Area management is needed by utilizing and maximizing internal and external factors. Based on the SWOT analysis, the $\mathrm{W}-\mathrm{T}$ strategy was chosen as the main priority with the biggest weight followed by the W-O, S-T and S-O strategies (Jabarullah et al., 2019).

5. The W-T strategy emphasizes on strengthening and drafting rules, supervising the implementation of rules, suppressing violations and socialization of the community.

\section{REFERENCES}

[1] Apriyani, R. (2017). Empat ekosistem danau di Indonesia 
sedang kritis. Available online: http://kbr.id/nasional/05 2017/empat_ekosistem_danau_di_indonesia_sedang_kritis _/90112.html (accessed on 21st of March 2018).

[2] Asdak C. 1995. Hidrologi dan Pengelolaan Daerah Aliran Sungai. UGM Press.

[3] D.N. Poerbondono \& E. Djunarsjah, 2005, Survey Hidrografi, Refika Aditama, Bandung.

[4] Ajiwibowo H, RHB Ash Shiddiq \& MB Pratama, "Assessment of Hydro-Environmental Condition Using Numerical Modelling in Dibawah Lake, Western Sumatera, Indonesia", International Journal of Geomate, vol 115, 2018, pp.140-146.

[5] Formen R, Siregar SH, Thamrin, "Analysis Strategy Development Town Forest (Case Study Area Raja Lake Sub Province Indragiri Pate)", Jurnal Ilmu Lingkungan, 2012:6 (1).

[6] Indrawaty N, Mulyadi A, Zulkarnain, "Evaluation of Land Use in Danau Buatan Rumbai Catchment Area at Pekanbaru City”, Jurnal Ilmu Lingkungan,2016:10 (1).

[7] ILEC, 2005, Managing lake and Their Basins for Sustainable Use, A Report for Lake Basin Management and Stakeholders. International Lake Environment Committee Foundation: Kutsasu, japan.

[8] Jabarullah, N.H., Shabbir, M.S., Abbas, M., Siddiqi, A.F. \& Berti, S. (2019) Using random inquiry optimization method for provision of heat and cooling demand in hub systems for smart buildings, Sustainable Cities and Society, https://doi.org/10.1016/j.scs.2019.101475.

[9] Lehmusluto, P\&B. Mahbub 1997. National Inventory of the Major Lakes and Reservoirs in Indonesian. General Limnology. Expedition Indodanau Technical Report. Indonesia-Finland. Revised Edition.

[10] Lukman \& Iwan R., 2006, Kondisi Daerah Tangkapan dan Ciri Morfometri Danau Lindu Sulawesi Tengah, Limnotek, Puslit Limnologi-LIPI.

[11] Ministry of Environment Republic of Indonesia, Profile of 15 National Priority Lakes, Ministry of Environment Republic of Indonesia, 2011.

[12] Ridwansyah I, "Kajian Morfometri, Zona Perairan dan Stratifikasi Suhu Danau Diatas Sumatera Barat', Limnotek, 2009, vol XVINo.1, p.22-32.

[13] Trisuryono, 2007, Kajian dan Pengembangan Karakteristik Limnologis Perairan Darat di Indonesia, Laporan Teknis DIPA 2007, Puslit Limnologi-LIPI. 